\title{
Effect of Planting Distance and Fertilizer Level on the Mineral Content of the Leaf of two Varieties of Carica papaya $\mathrm{L}^{1}$.
}

\begin{abstract}
Agripino Pérez López z
ABSTRACT

Ten-month-old papaya plants of variety P.R. 6-65 contained significantly more $\mathrm{N}, \mathrm{P}, \mathrm{K}$ and $\mathrm{Ca}$, lower $\mathrm{K}$ and $\mathrm{Mg}$ in blades, than plants of variety P. $\mathrm{P}$. 765 , and equal content of $\mathrm{Mn}$. The petioles in variety P.R. 7-65 had significantly more $\mathrm{Mn}$ and $\mathrm{K}$, but less $\mathrm{Mg}$ and $\mathrm{Ca}$ than those of variety P.R. 6-65, and equal contents of $\mathrm{N}$.

$\mathrm{N}$ in the blades in the two varieties at two planting distances decreased, while $\mathrm{N}$ in the petioles increased as the age of the plants increased.

The $P$ content in the blades of plants of the two varieties and the lwo spacings decreased as the age of the plants increased, while in the petioles this reduction was significant only at the planting distance of $1.8 \times 1.8 \mathrm{~m}$. At the $1.2 \times 1.2 \mathrm{~m}$ planifing distance, the $P$ in the petioles of variety P.R. $6-65$ was not significantly affected by the plant age, but in varlety P.R. 7-65 P increased significantly with the age of the plant.

$K$ in the blades and petioles of variety P.R. 6-65 at 10 and 23 months decreased significantly as the planting distance increased. In variety P.R. 765 , similar results were found in 23 -month-old plants but not in those 10 months old.

The $\mathrm{Ca}$ and $\mathrm{Mn}$ content in the blades and petioles were not affected by the planting cistance or by the fertilizer supplied to the plants.

$\mathrm{Mg}$ in the blades of P.R. 7-65 decreased as the planting distance increased, and did not vary in variety P.R. 6-65; there was a significant interaction of fertilizer $x$ distance. The significant second order interaction of fertilizer $x$ distance $\times$ variety for the $\mathbf{M g}$ content of the petioles suggests that the varieties responded differently to the fertilizer supplied at the two distances.
\end{abstract}

\section{INTRODUCTION}

Papaya nutrition has not been studied thoroughly in Puerto Rico. Cibes and Gastambide (1) reported deficiencies under controlled conditions, and several reports $(2,3,4,5)$ have been published by Pérez-López et al.

Limited yields of papaya in Puerto Rico are probably due to the lack of information about planting distances and nutrient requirements of the varieties. Therefore, this study was designed to determine the effect of two planting distances and two fertilizer levels on the $\mathrm{N}, \mathrm{P}, \mathrm{K}, \mathrm{Ca}, \mathrm{Mg}$, and $\mathrm{Mn}$ content of blades and petioles of varieties P.R. 6-65 and P.R. 765.

\section{MATERIALS AND METHODS}

This paper follows previous publications $(2,6)$, in which location, soil type, rainfall, fertilization and orchard management are discussed.

\footnotetext{
'Manuscript submilted to Editorial Board March 31, 1981.

${ }^{2}$ Horticulturist and Horticulture Professor, Agric. Lxp. Stn. Mayagüez Campus, Univ. P.R., Río Piedras, P.R.
} 
The planting distances were $1.2 \times 1.2 \mathrm{~m}$ and $1.8 \times 1.8 \mathrm{~m}$, and the fertilizer levels were 227 and $454 \mathrm{~g} /$ plant/month of a 15-15-15 commercial fertilizer. The varieties were P,R, 6-65 and P.R. 7-65. The treatments were initiated when the first flower opened in about $30 \%$ of the plants.

When the plants were 10 and 23 months old, four leaves per plot (blades and petioles separated as individual samples) were collected, washed and dried to a constant weight in a forced air oven at $70^{\circ} \mathrm{C}$ and analyzed for $\mathrm{N}, \mathrm{P}, \mathrm{K}, \mathrm{Ca}, \mathrm{Mg}$, and $\mathrm{Mn}$. $\mathrm{Ca}, \mathrm{Mg}$ and $\mathrm{Mn}$ were analyzed only in plants 10 months old. All data were evaluated by Duncan's Multiple Range Test:

TABLE 1.-Effect of planting distance and fertilizer level on the nitrogen content of blades and petioles of 10- and 23-month old plants of the P.R. 6-65 and P.R. 7-65 papaya varieties

\begin{tabular}{|c|c|c|c|c|c|c|c|}
\hline \multirow{4}{*}{$\begin{array}{l}\text { Planting } \\
\text { distance }\end{array}$} & \multirow{4}{*}{ Leaf' } & \multicolumn{6}{|c|}{ Varieties } \\
\hline & & \multirow{2}{*}{\multicolumn{2}{|c|}{$\begin{array}{c}\text { PIR 6-65 } \\
\text { Fertilizer leve] } \\
\text { (g) }\end{array}$}} & \multirow{3}{*}{ Mean } & \multirow{2}{*}{\multicolumn{2}{|c|}{$\begin{array}{c}\text { l'R } 7-65 \\
\text { Fertilizer level }\end{array}$}} & \multirow{3}{*}{ Mean } \\
\hline & & & & & & & \\
\hline & & 227 & 454 & & 227 & 454 & \\
\hline \multirow[t]{2}{*}{$M$} & & $\%$ & q & 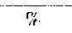 & $\%$ & 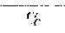 & $?$ \\
\hline & & & \multicolumn{2}{|c|}{10 months } & & \\
\hline \multirow[t]{2}{*}{$1.2 \times 1.2$} & Blade & 5.17 & 5.13 & 5. $15 \mathrm{a}^{1}$ & $5.15 a$ & $5.02 \mathrm{a}$ & 5.096 \\
\hline & Petiole & 1.25 & 1.13 & $1.19 a$ & 1.26 & 1.29 & $1.27 \mathrm{a}$ \\
\hline \multirow[t]{3}{*}{$1.8 \times 1.8$} & Blade & 5.24 & 5.30 & $5.27 \mathrm{a}$ & 4.79 & 4.99 & $4.89 \mathrm{~b}$ \\
\hline & Petiole & 1.14 & 1.20 & $1.17 \mathrm{a}$ & 1.07 & 1.09 & $1.08 \mathrm{~b}$ \\
\hline & & \multicolumn{5}{|c|}{23 months } & \\
\hline \multirow[t]{2}{*}{$1.2 \times 1.2$} & Blade & 3.56 & 3.72 & $3.64 a$ & 4.43 & 3.60 & $4.02 \mathrm{a}$ \\
\hline & Petiole & $1.29 \mathrm{~b}$ & $1.60 \mathrm{a}$ & $1.45 \mathrm{a}$ & 1.19 & 1.42 & L.31a \\
\hline \multirow[t]{2}{*}{$1.8 \times 1.8$} & Blade & 3.40 & 3.62 & $3.51 \mathrm{a}$ & 3.68 & 3.633 & 3.669 \\
\hline & Petiole & $1.21 \mathrm{a}$ & $1.22 \mathrm{a}$ & $1.2 \mathrm{Ib}$ & 1.12 & 1.23 & $1.18 \mathrm{~b}$ \\
\hline
\end{tabular}

'Means in rows and columns followed by the same letter do not differ siguificantly at 0.05 probability level.

\section{RESULTS AND DISCUSSION}

Since the content of most of the elements studied in these experiments was not affected as the fertilizer level was increased, the $227 \mathrm{~g} / \mathrm{plant} /$ month of the same 15-15-15 commercial fertilizer should be ample to grow papaya spaced $1.8 \times 1.8 \mathrm{~m}$, the best spacing as confirmed in a previous report (2).

\section{NITROGEN}

Table 1 shows the $\mathrm{N}$ content of blades and petioles of plants 10 and 23 months old. ln both 10 - and 23-month old plants the petioles of plants planted $1.8 \times 1.8 \mathrm{~m}$ apart had significantly lower $\mathrm{N}$ content than those planted $1.2 \times 1.2 \mathrm{~m}$. The table also shows that in 10 -month-old plants, $\mathrm{N}$ 
content of the blade in variety P.R. 6-65 was significantly higher (5.21) than that of variety P.R. 7-65, which was 4.99 (table 2). When the plants of both varieties were 23 months old, those fertilized with $454 \mathrm{~g}$ of fertilizer and planted at $1.2 \times 1.2 \mathrm{~m}$ had significantly more $\mathrm{N}$ than those planted at $1.8 \times 1.8 \mathrm{~m}$ and fertilized with $227 \mathrm{~g}$ of fertilizer.

Table 1 also shows that the $N$ content of the blades, when the plants were 10 months old, was five times higher than that of the petioles, and that as the plant's age increased from 10 to 23 months, the $\mathrm{N}$ content of the blade decreased while that of the petioles increased.

Table 2 shows that the $\mathrm{N}$ content of the petioles in the 10-month-old plants of P.R. 6-65 and P.R. 7-65 was about equal and that the $\mathrm{N}$ content of the blade was significantly higher in P.R. 6-65 than in the blade of P.R. 7-65. In both varieties the blade $N$ content; was five times higher than that of the petioles.

TABLE 2.-Blade and petiole element content of 10-month-old plants of the P.R. 6-65 and P.R. 7.65 papaya varieties

\begin{tabular}{|c|c|c|c|c|c|c|}
\hline \multirow{2}{*}{ Variety } & \multicolumn{6}{|c|}{ Filements. } \\
\hline & $\mathrm{N}$ & P & $\mathrm{K}$ & $\mathrm{Ca}$ & $\mathrm{Mg}_{\mathrm{g}}$ & $M_{n}$ \\
\hline & $\%$ & $\%$ & $y$ & $\%$ & q & $p / m$ \\
\hline & \multicolumn{6}{|c|}{ Blade } \\
\hline P.R. 6-65 & $5.21 \mathrm{a}^{1}$ & $0.42 \mathrm{a}$ & $2.66 \mathrm{~b}$ & $3.00 a$ & 1.136 & $129 a$ \\
\hline \multirow{2}{*}{ P.R. 7-65 } & $4.99 \mathrm{~b}$ & $0.39 \mathrm{~b}$ & $2.95 a$ & $2.56 \mathrm{~b}$ & I. $24 a$ & $152 \mathrm{a}$ \\
\hline & \multicolumn{6}{|c|}{ Peliole } \\
\hline P.R. 6-65 & $1.18 \mathrm{a}$ & $0.17 \mathrm{a}$ & $2.35 b$ & $2.76 \mathrm{a}$ & $0.7 \mathrm{la}$ & $59 \mathrm{~b}$ \\
\hline P.R. 7.65 & $1.18 \mathrm{a}$ & $0.15 \mathrm{a}$ & $3.20 \mathrm{a}$ & $2.23 \mathrm{~b}$ & $0.65 \mathrm{~b}$ & $73 a$ \\
\hline
\end{tabular}

'See table 1 .

\section{PHOSPHORUS}

Table 3 shows that the $\mathrm{P}$ content of the blades and petioles in 10month old plants planted $1.8 \times 1.8 \mathrm{~m}$ was significantly higher than that of plants of the same age planted $1.2 \times 1.2$. This tendency disappeared when these same plants were 23 months old.

At 10 months there were no significant differences in $\mathrm{P}$ content of blades and petioles, respectively of the two varieties. At 23 months old the $P$ content of the petiole of variety P.R. 7-65 was affected significantly only by the planting distance; i.e., plants at $1.2 \times 1.2 \mathrm{~m}$ contained significantly more $P$ than those planted at $1.8 \times 1.8 \mathrm{~m}$.

Table 2 also shows that in 10-month-old plants, the $P$ content of the petioles in the two varieties was about equal, but the $P$ content of the blades of variety P.R. 6-65 was significantly higher than that of variety P.R. 7-65. In both varieties, the $P$ content of the blade was twice that of the petioles. 
POTASSIUM

Table 4 shows that variety P.R. 6-65 10 and 23 months old, contained significantly lower $\mathrm{K}$ in the petioles than P,R. 7-65. For the blade content, this was not the case, since the interaction between fertilizer $\times$ variety was significant for the $\mathrm{P}$ content of the blades in the 23-month old plants. In the 10-month old plants, blade $\mathrm{K}$ content was higher in a highly significant way in variety P.R. 7-65 than in P.R. 6-65.

In 23-month-old plants of the two varieties the $\mathrm{K}$ content of blades and petioles of plants planted $1.2 \times 1.2 \mathrm{~m}$ was higher in a highly significant way than the $\mathrm{K}$ content in those planted $1.8 \times 1.8 \mathrm{~m}$.

The interactions between variety $\times$ distance, and variety $\times$ fertilizer were highly significant only on blades of 10 - and 23-month-old plants.

TABLE 3.-Effect of planting distance and fertilizer level on the phosphorus cuntent of blades and petioles of 10. and 23-month old plants of P.R. 6-65 and P.R. 7-65 papaya varieties

\begin{tabular}{|c|c|c|c|c|c|c|c|}
\hline \multirow{3}{*}{$\begin{array}{l}\text { Planting } \\
\text { distance }\end{array}$} & \multirow{3}{*}{ Lenf } & \multicolumn{6}{|c|}{ Varieties } \\
\hline & & \multicolumn{2}{|c|}{$\begin{array}{c}\text { P.R. 6-6is } \\
\text { Fertilizer level } \\
\text { (g) }\end{array}$} & \multirow[t]{2}{*}{ Mean } & \multicolumn{2}{|c|}{$\begin{array}{c}\text { P.R. 7-65 } \\
\text { Fertiilizer level }\end{array}$} & \multirow[t]{2}{*}{ Mean } \\
\hline & & 227 & 454 & & 227 & 454 & \\
\hline \multirow[t]{2}{*}{$M$} & & $\%$ & $\%$ & $\%$ & $\%$ & $\%$ & $\%$ \\
\hline & & \multicolumn{6}{|c|}{10 months } \\
\hline \multirow[t]{2}{*}{$1.2 \times 1.2$} & Blade & 0.39 & 0.41 & $0.40 \mathrm{~b}^{\prime}$ & 0.37 & 0.37 & $0.37 \mathrm{~b}$ \\
\hline & Petiole & 0.15 & 0.16 & $0.16 b$ & 0.13 & 0.13 & $0.13 b$ \\
\hline \multirow[t]{3}{*}{$1.8 \times 1.8$} & Blade & 0.42 & 0.44 & $0.43 \mathrm{a}$ & 0.39 & 0.49 & $0.40 \mathrm{a}$ \\
\hline & Petiole & 0.17 & 0.21 & $0.19 a$ & 0.18 & 0.16 & $0.17 \mathrm{a}$ \\
\hline & & & & \multicolumn{3}{|c|}{23 ntonths } & \\
\hline \multirow[t]{2}{*}{$1.2 \times 1.2$} & Blade & 0.34 & 0.36 & $0.35 \mathrm{a}$ & 0.36 & 0.35 & $0,35 \mathrm{~b}$ \\
\hline & Petiole & 0.15 & 0.16 & $0.16 a$ & 0.15 & 0.16 & $0.16 \mathrm{a}$ \\
\hline \multirow[t]{2}{*}{$1.8 \times 1.8$} & Blade & 0.32 & 0.36 & $0.34 \mathrm{a}$ & 0.39 & 0.35 & $0.37 a$ \\
\hline & Petiole & 0.15 & 0.15 & $0.15 a$ & 0.14 & 0.14 & $0.14 \mathrm{~b}$ \\
\hline
\end{tabular}

'Means in columns followed by the same letter do not differ significantly at the 0.06 probability level.

These interactions may have been significant because P.R. 7-65 is an early variety, while P.R. $6-65$ is a late one. Therefore, they responded differently to the amount of fertilizer applied.

Since no significant differences were attributed to fertilizer amounts, $227 \mathrm{~g}$ or $454 \mathrm{~g}$, no more than $227 \mathrm{~g} /$ plant/month should be applied.

Table 2 shows that at 10 months P.R. 7-65 contained significantly more $K$ in the blades and petioles than P.R. 6-65. In P.R. 7-65 differences between the $\mathrm{K}$ content of blades and petioles were nonsignificant.

\section{CALCIUM}

Tables 2 and 4 show that variety P.R. 6-65 contained more $\mathrm{Ca}$ in a highly significant way in blade and petiole than variety P.R. 7-65, and 
that the fertilizer level and planting distance did not affect significantly the $\mathrm{Ca}$ content of these plant tissues in 10-month-old plants. Both tables show that there is not a great difference between the Ca content of blades and petioles in either variety.

\section{MAGNESIUM}

Table 5 shows that variety P.R. 6-65 had a significantly lower $\mathrm{Mg}$ content in the blade and a higher content in the petiole than P.R. 7-65. This table also shows that the $\mathrm{Mg}$ content of the blades of plants planted $1.2 \times 1.2 \mathrm{~m}$ was higher in a highly significant way than that of the plants planted $1.8 \times 1.8 \mathrm{~m}$. However, there was no difference in the $\mathrm{Mg}$ content of the petioles.

The interactions between fertilizer $\times$ distance and fertilizer $\times$ distance $\times$ variety were significant, indicating that $\mathrm{Mg}$ content is affected by the variables studied in this experiment.

TARIE 4,-Effect of planting distance and fertilizer level on the potassium content of blades and petioles of 10-and 23-month old plants of the P.R. 6.65 and P.R. 7.65 papaya varieties

\begin{tabular}{|c|c|c|c|c|c|c|c|}
\hline \multirow{3}{*}{$\begin{array}{l}\text { Planting } \\
\text { distance }\end{array}$} & \multirow{3}{*}{ Leaf } & \multicolumn{6}{|c|}{ Varieties } \\
\hline & & \multicolumn{2}{|c|}{$\begin{array}{c}\text { P.R. } 6-65 \\
\text { Fertilizer level } \\
\text { (g) }\end{array}$} & \multirow[t]{2}{*}{ Mean } & \multicolumn{2}{|c|}{$\begin{array}{c}\text { P.R. } 7-65 \\
\text { Fertilizer level } \\
\text { (g) }\end{array}$} & \multirow[t]{2}{*}{ Mean } \\
\hline & & 227 & 454 & & 227 & 454 & \\
\hline \multirow[t]{2}{*}{$M$} & & o & is & $\%$ & $\%$ & q & $\%$ \\
\hline & & \multicolumn{6}{|c|}{10 months } \\
\hline \multirow[t]{2}{*}{$1.2 \times 1.2$} & Blade & 2.65 & 2.76 & $2.71 \mathrm{a}^{l}$ & 2.67 & 3.01 & $2.84 \mathrm{~b}$ \\
\hline & Petiole & 2.27 & 2.59 & $2.43 a$ & 2.98 & 3.19 & $3.09 a$ \\
\hline \multirow[t]{3}{*}{$1.8 \times 1.8$} & Blade & 2.50 & 2.45 & $2.48 \mathrm{~b}$ & 3.19 & 2.92 & $3.06 a$ \\
\hline & Petiole & 2.02 & $2.5 \mathrm{I}$ & $2.27 \mathrm{a}$ & 3.64 & 2.99 & $3.32 a$ \\
\hline & & \multicolumn{6}{|c|}{23 months } \\
\hline \multirow[t]{2}{*}{$1.2 \times 1.2$} & Blade & 2.72 & 3.07 & $2.99 \mathrm{a}$ & 3.17 & 2.71 & $2.94 \mathrm{a}$ \\
\hline & Petiole & 2.27 & 2.80 & $2,54 a$ & 3.50 & 3.27 & $3.39 a$ \\
\hline \multirow[t]{2}{*}{$1.8 \times 1.8$} & Blade & 1.90 & 2.34 & $2.12 \mathrm{~b}$ & 2.58 & 2.48 & $2.53 \mathrm{~b}$ \\
\hline & Petiole & 1.52 & 1.26 & $1.39 \mathrm{~b}$ & 2.44 & 1.96 & $2,20 \mathrm{~b}$ \\
\hline
\end{tabular}

'See table 1.

Table 2 shows that the 10-month-old plants of variety P.R. 6-65 contained significantly less $\mathrm{Mg}$ in the blades and more in the petiole than those of P.R. 7-65, and that the $\mathrm{Mg}$ content in the blades of both varieties was twice that of the petioles.

\section{MANGANESE}

Table 5 shows that $\mathrm{Mn}$ content of blades and petioles in neither P.R. 6-65 nor P.R. 7-65 was affected by planting distance and fertilizer levels. It also shows that the $\mathrm{Mn}$ content of the petiole of variety P.R. 7-65 was significantly lower than that of variety P.R. 6-65. 
Tables 2 and 5 also show that the $\mathrm{Mn}$ in the blades of the two varieties did not differ significantly and that the blades in both varieties contained twice as much as the petioles.

\section{RESUMEN}

La producción de papaya en Puerto Rico es baja porque además del problema de enfermedades no hay suficiente información con respecto al abonamiento de este frutal.

ТАВиг 5.-Effect of planting distance and fertilizer level on the calcium, magnesium. and manganese content of blades and petioles of 10 -month-old plants of P.R. 6.65 and P.R. 7-65 papaya varieties

\begin{tabular}{|c|c|c|c|c|c|c|c|}
\hline \multirow{4}{*}{$\begin{array}{l}\text { Planting } \\
\text { distance }\end{array}$} & \multirow{4}{*}{ Lear } & \multicolumn{6}{|c|}{ Varieties } \\
\hline & & \multirow{2}{*}{\multicolumn{2}{|c|}{$\begin{array}{c}\text { P.R. } 6-65 \\
\text { Fertilizer level } \\
(\mathrm{g})\end{array}$}} & \multirow{3}{*}{ Mean } & \multirow{2}{*}{\multicolumn{2}{|c|}{$\begin{array}{l}\text { P'.TR. } 7-65 \\
\text { Ferlilizer level } \\
\text { (g) }\end{array}$}} & \multirow{3}{*}{ Mean } \\
\hline & & & & & & & \\
\hline & & 227 & 454 & & & 454 & \\
\hline \multirow[t]{2}{*}{$M$} & & $\%$ & $\%$ & s & $" \eta$ & $\%$ & $\%$ \\
\hline & & \multicolumn{6}{|c|}{ Calcium } \\
\hline \multirow[t]{2}{*}{$1.2 \times 1.2$} & Blade & 2.93 & 3.08 & $2.92 \mathrm{a}^{\mathrm{r}}$ & 2.70 & 2.53 & $2.62 \mathrm{a}$ \\
\hline & Petiole & 2.49 & 2.70 & $2.60 \mathrm{a}$ & 1.99 & 2.04 & $2.02 \mathrm{a}$ \\
\hline \multirow[t]{2}{*}{$1.8 \times 1.8$} & Blade & 2.92 & 3.06 & $2.99 \mathrm{a}$ & 2.49 & 2.52 & $2.5 \mathrm{Ia}$ \\
\hline & Petiole & 2.82 & 2.91 & $2.87 \mathrm{a}$ & 2.82 & 2.08 & $2.45 \mathrm{a}$ \\
\hline . & & \multicolumn{6}{|c|}{ Magnesium } \\
\hline \multirow[t]{2}{*}{$1.2 \times 1.2$} & Blade & 1.20 & $\mathrm{~J} .17$ & $1.19 a$ & 1.42 & 1.35 & $1.39 \mathrm{a}$ \\
\hline & Petiole & 0.68 & 0.69 & $0.69 \mathrm{a}$ & 0.72 & 0.62 & $0.67 \mathrm{a}$ \\
\hline \multirow[t]{4}{*}{$1.8 \times 1.8$} & Blade & 0.99 & 1.18 & $\mathrm{I} .09 \mathrm{~b}$ & 1.00 & 1.21 & $1.1 \mathrm{Ib}$ \\
\hline & Petiole & 0.76 & 0.72 & $0.74 \mathrm{a}$ & 0.59 & 0.67 & $0.613 \mathrm{a}$ \\
\hline & & \multicolumn{6}{|c|}{ Manganese } \\
\hline & & $p / m$ & $p / m$ & $p / m$ & $p / m$ & $p / m$ & $p / m$ \\
\hline \multirow[t]{2}{*}{$1.2 \times 1.2$} & Blade & 141 & 135 & $138 \mathrm{a}$ & 123 & 175 & $149 a$ \\
\hline & Petiole & 66 & 59 & 634 & 61 & 76 & $68 \mathrm{a}$ \\
\hline \multirow[t]{2}{*}{$1.8 \times 1.8$} & Blade & 104 & 135 & $120 \mathrm{a}$ & 132 & 177 & $\lfloor 54 a$ \\
\hline & Petiole & 57 & 54 & $56 a$ & 70 & 84 & $77 a$ \\
\hline
\end{tabular}

'See table 3.

En este estudio se usaron variedades de alta producción para comparar el efecto de dos densidades de siembra y dos niveles de abono 15-15-15 en el contenido en $\mathrm{N}, \mathrm{P}, \mathrm{K}, \mathrm{Ca}, \mathrm{Mg}$ y $\mathrm{Mn}$ de las láminas y pecíolos del papayo.

Plantas de la variedad P.R. 6-65 de 10 meses de edad contenian significativamente más $\mathrm{N}, \mathrm{P}$ y Ca y menos $\mathrm{K}$ y Mg en las láminas e igual contenido de $\mathrm{Mn}$ que plantas de la misma edad de la variedad P.R. 7-65. Los pecíolos de la variedad P.R. 7-65 contenian significativamente más $\mathrm{Mn}$ y $\mathrm{K}$ y menos $\mathrm{Mg}$ y $\mathrm{Ca}$, e igual porcentaje de $\mathrm{P}$ y $\mathrm{N}$ que la variedad P.R. 6-65.

Las plantas de 10 y 23 meses de edad de la variedad P.R. 6-65 sembradas a $1.2 \times 1.2 \mathrm{~m}$ contenían significativamente más $\mathrm{N}$ en los 
pecíolos, más $\mathrm{K}$ en la lámina y pecíolo y menos $\mathrm{P}$ en los pecíolos (plantas de 10 meses de edad) que las espaciadas a $1.8 \times 1.8 \mathrm{~m}$.

EI $N$ en la lámina de las dos variedades y en las dos densidades se redujo, mientras que en el peciolo aumentó a mayor edad de los papayos.

El contenido en $\mathrm{P}$ de las láminas de las dos variedades en las dos densidades se redujo a mayor edad de las plantas, mientras que en el peciolo esta reducción se observó solamente en las sembradas a 1.8 $\times 1.8 \mathrm{~m}$. En las sembradas a $1.2 \times 1.2 \mathrm{~m}$, el $\mathrm{P}$ en los peciolos de la variedad P.R. 6-65 no se afectó con la edad de la planta, pero en la P.R. 7-65 éste aumentó cuando era más vieja.

El contenido en $\mathrm{K}$ en las láminas y peciolos de plantas de 10 y 23 meses de edad de la variedad P.R. 6-65 se redujo significativamente cuando se redujo la densidad de siembra. Hubo un efecto igual en plantas de la variedad P.R. 7-65 de 23 meses de edad y lo opuesto en las de 10 meses de esta misma variedad.

El contenido en $\mathrm{Mg}$ de la lámina de las plantas de la variedad P.R. 765 se redujo según se redujo la densidad de siembra pero no así en la variedad P.R. 6-65. En este caso, la interacción de abono $x$ densidad fue significativa. Con respecto al contenido en $\mathrm{Mg}$ en el pecíolo, la interacción de abono $x$ densidad $x$ variedad fue significativa, lo cual sugiere que con respecto a este nutrimento los papayos respondieron diferentemente cuando se aplicaron los dos niveles de abono en las dos densidades de siembra.

\section{IITERATURE CITED}

I. Cibes, H. K. and Gaztambide, S., 1978. Mineral deficiency symploms displayed by papaya plants grown under controlled conditions, J. Agric. Univ. P.R. 62 (4): 413-23.

2. Pérez, A. and Vargas, D., 1977. Effect of fertilizer level and planting distance on soil $\mathrm{pH}$, growth, fruit size, disease incidence, yield and profit of two papaya varieties, J. Agric. Univ. P.R. 61 (1): 68-76.

3. and Childers, N. F., 1982. Growth, yield, nutrient content and fruit quality of Carica papaya L. under controlled conditions. I. Nitrogen effects. J. Agric. Univ. P.R. 66 (2): 71-79.

4. and 1982. Growth, yield, nutrient content and fruit quality of Carica papaya L. under controlled conditions. IL. Boron effects. J. Agric. Univ. P.R. 66 (2): 80-88.

5. and Reyes-Jurado, Rubén D., 1982. Effect of nitrogen and boron application on Carica papaya L. I. Growth and Yield. J. Agric. Univ. P.R. 66 (3): D.

6. Sing, T. and Vargas, D., 1977, Conjunto Tecnológico para la Producción de Papaya. Esta. Exp. Agric. Univ. P.R., Publ. 117. 